\title{
PF-bonded particleboards from AKD-modified chips
}

\author{
Ulrich Hundhausen · Holger Militz · Carsten Mai
}

Received: 20 January 2009 / Published online: 31 July 2009

(C) Springer-Verlag 2009

\begin{abstract}
Alkyl ketene dimer (AKD) was used as a hydrophobic agent for PF-bonded particleboards. In contrast to conventionally used paraffin, AKD can be covalently bonded to the chip surface by esterification with wood hydroxyl groups. FTIR analyses before and after toluene extractions indicated that only a small amount of the applied AKD is chemically bonded. Wettability studies on veneer strips suggested that particularly the bonded AKD accounts for the surface hydrophobicity.

A subsequent spraying of AKD and PF resin on the chips that were pressed for 15, 30, and $60 \mathrm{~s} \mathrm{~mm}^{-1}$ (Process 1) did not result in decreased thickness swelling and water uptake as compared to the control boards. In Process 2, chips were cured $\left(130^{\circ} \mathrm{C} / 6,12,24 \mathrm{~h}\right)$ prior to pressing $\left(15 \mathrm{~s} \mathrm{~mm}^{-1}\right)$ which did not impart significant hydrophobicity either. The low efficacy of AKD as hydrophobic agent in Process 1 is attributed to the hydrolysis of AKD by water vapor during pressing. The low hydrophobic effect of AKD in Process 2 is ascribed to a saponification of esters between AKD and wood hydroxyl groups by the alkaline PF resin.
\end{abstract}

\footnotetext{
U. Hundhausen $(\bowtie)$
}

Norsk Treteknisk Institutt,

Forskningsveien 3B,

P.O. Box 113 Blindern, 0314 Oslo, Norway

e-mail: ulrich.hundhausen@ treteknisk.no

H. Militz $\cdot$ C. Mai

Wood Biology and Wood Products, Burckhardt Institute,

Georg-August-University Göttingen,

Büsgenweg 4,

37077 Göttingen, Germany

\section{PF-gebundene Spanplatten aus AKD-behandelten Spänen}

Zusammenfassung Alkylketendimer (AKD) wurde als Hydrophobierungsmittel für PF gebundene Spanplatten verwendet. Im Gegensatz zu konventionell eingesetztem Paraffin kann AKD die Hydroxylgruppen des Holzes verestern und so auf der Spanoberfläche fixiert werden. FTIR Analysen vor und nach Toluolextraktionen ergaben, dass lediglich eine geringe Menge des aufgebrachten AKD kovalent gebunden vorlag. Untersuchungen der Benetzbarkeit von Furnierproben zeigten, dass hautsächlich das gebundene AKD die Hydrophobierung bewirkt.

Das schrittweise Aufsprühen von AKD und PF Leim auf die Späne, die nachfolgend bei 15, 30 und $60 \mathrm{~s} \mathrm{~mm}^{-1}$ verpresst wurden (Prozess 1), ergab keine Verringerung der Dickenquellung und Wasseraufnahme im Vergleich zu den Kontrollplatten. Im zweiten Prozess wurden die mit AKD beaufschlagten Späne vor dem Pressen $\left(15 \mathrm{~s} \mathrm{~mm}^{-1}\right)$ getrocknet $\left(130^{\circ} \mathrm{C} / 6,12,24 \mathrm{~h}\right)$, was ebenfalls zu keiner nennenswerten Hydrophobierung der Platten führte. Die geringe Wirksamkeit von AKD im ersten Prozess wird auf eine Hydrolyse des AKD durch Wasserdampf während des Pressens zurückgeführt. Die geringe Hydrophobierung im zweiten Prozess basiert vermutlich auf einer Verseifung der Ester zwischen AKD und den Hydroxylgruppen des Holzes durch den alkalischen PF Leim.

\section{Introduction}

Poor dimensional stability under changing moisture conditions is a major drawback of reconstituted wood products. Paraffin wax emulsions in amounts of $0.3-1.0 \%(\mathrm{wt} / \mathrm{wt})$ are usually applied to provide temporary water repellence when 
boards are wetted; however, paraffin cannot impart durable protection against liquid water and has basically no effect on dimensional changes under equilibrium moisture conditions (Youngquist 1999, Roffael et al. 2005).

Hundhausen et al. (2009a,b) investigated the potential of the paper sizing chemical alkyl ketene dimer (AKD) as a reactive hydrophobic agent for particleboards. AKD can be theoretically bound to the chip surface by esterifying wood hydroxyl groups in contrast to paraffin. AKD belongs to the class of cellulose reactive sizes and it is widely believed that its hydrophobic effect is based on a covalent anchorage on fibers (Davis et al. 1956, Lindström and Söderberg 1986a, Nahm 1986, Neimo 1999, Hubbe 2006).

The previous studies on UF-bonded particleboards have demonstrated that AKD improves water repellence considerably when chips were cured at $130^{\circ} \mathrm{C}(6,12$, and $24 \mathrm{~h})$ prior to pressing (Hundhausen et al. 2009b). The main disadvantage was that the increased dimensional stability was associated with strongly reduced internal bond strength (IB). The present study is a follow-up of the earlier investigations, aiming at improving the bonding between AKDtreated chips by using PF resin. A treatment with AKD in combination with a hydrolysis-resistant adhesive is expected to increase and extend water resistance of panels for applications in Use Class 3.

\section{Experimental}

\subsection{Chemical treatment of wood chips}

Chips were treated with an AKD dispersion (Hydrores 452N, Kemira, Leverkusen, Germany; $1 \%$ active AKD based on dry chip mass) using two different processes: 1) AKD and PF resin were successively sprayed on the wood chips; 2) chips were sprayed with AKD and subsequently cured in a dryer at $130^{\circ} \mathrm{C}$ before gluing and pressing. Three different curing times $(6,12$, and $24 \mathrm{~h})$ were employed. As paraffin reference served HydroWax 138 (solid content 50\%) from Sasol (Hamburg, Germany). Boards made from untreated chips were used as controls.

\subsection{Panel manufacturing and testing}

Each treatment was represented by three particleboards with a target density of $700 \mathrm{~kg} \mathrm{~m}^{-3}$. The 3-layered panel structure showed a mass distribution of 20: 60:20\% (face : core: face). The mesh size distribution of the core layer chips was 3,10 , $19,14,38,16 \%(<0.5,>0.5,>1.0,>1.6,>2.0,>4.0 \mathrm{~mm})$, and of the face layer chips $11,7,14,46,14,5,3 \%(<0.125$, $>0.125,>0.2,>0.4,>0.8,>1.0,>1.25 \mathrm{~mm})$. The wood chips (Pfleiderer, Gütersloh, Germany) were sprayed in a laboratory blender with PF resins (Bakelite, Duisburg,
Germany). The amount was $9 \%$ in the core layer (1842 HW; solid content $48 \%)$ and $12 \%$ in the face layer $(2506 \mathrm{HW}$; solid content $46 \%$ ). HW 1842 was blended with potassium carbonate (6\% based on resin solid weight) as a hardener.

Resinated chips were spread by hand to mats in a wooden frame $\left(450 \times 450 \mathrm{~mm}^{2}\right)$. The mats were hot-pressed $\left(200^{\circ} \mathrm{C}\right)$ in a platen press to $20 \mathrm{~mm}$ thickness (HP-S 200, Joos, Pfalzgrafenweiler, Germany). The pressing time was $15 \mathrm{~s} \mathrm{~mm}^{-1}$ for both processes. Extended times of 30 and $60 \mathrm{~s} \mathrm{~mm}^{-1}$ were also employed in Process 1 . The core temperature course was measured in one control board. Boards were sanded to $19 \mathrm{~mm}$, trimmed to $410 \times 410 \mathrm{~mm}^{2}$, and cut to test specimens between 48 and $72 \mathrm{~h}$ after pressing. They were conditioned to equilibrium moisture content $\left(20^{\circ} \mathrm{C} / 65 \%\right.$ $\mathrm{RH})$ and tested for $24 \mathrm{~h}$ thickness swelling (EN 317; $n=$ 30 ), internal bond strength (EN $319 ; n=30)$, modulus of rupture (DIN $52362 ; n=9)$, and $24 \mathrm{~h}$ water uptake $(n=30)$.

\subsection{FTIR analyses}

AKD-treated $\left(130^{\circ} \mathrm{C} / 24 \mathrm{~h}\right)$ core layer chips and parts of a spruce veneer were FTIR-analyzed. The veneer $(120 \times$ $\left.120 \times 0.7 \mathrm{~mm}^{3}\right)$ was sprayed with AKD and dried $\left(130^{\circ} \mathrm{C} /\right.$ $1.5 \mathrm{~h}$ ) resulting in a weight percent gain (WPG) of $7.5 \%$. Other parts of the veneer were used for measuring the surface wettability and the $\mathrm{pH}$ value after cold water extraction.

The measurements were taken with a FTIR spectrometer Vector 22 (Bruker, Bremen, Germany) with an ATR unit (DuraSamplIRII, SensIR Technologies, Danbury, USA) operating on 32 scans and at $4 \mathrm{~cm}^{-1}$ resolution. The spectra were base-line corrected and normalized to the lignin peak at $\approx 1505 \mathrm{~cm}^{-1}$. The profile of the ATR stamp was marked to measure the same point before AKD treatment, after treatment, and after Soxhlet extraction with toluene (12 h).

\subsection{Surface wettability}

The surface wettability of veneer strips was determined by measuring the cumulative area increase of PF glue (1842 HW, Bakelite, Duisburg, Germany, solid content of $48 \%$ ), UF glue (Kaurit 350, BASF, Ludwigshafen, Germany, solid content of $66.5 \%$ ), and deionized water droplets.

The veneer pieces were conditioned at $20^{\circ} \mathrm{C} / 65 \% \mathrm{RH}$ prior to measuring the area extensions of deionized water droplets $(7 \mu \mathrm{l})$ that were stained with picrine aniline blue $(5 \%)$. The droplets $(n=15)$ were suspended from a micropipette and randomly placed on the veneers. The extension was recorded with a digital camera (DXM 1200, Nikon, Düsseldorf, Germany) through a reflected light microscope (S8AP0, Leica, Wetzlar, Germany) that was connected to a computer. The photo software Lucia Image (Version 1.4.3.67) took pictures at a rate of $10 \mathrm{~s}$ 
for a total duration of $180 \mathrm{~s}$. The measurements were repeated after the strips had been extracted with toluene for $12 \mathrm{~h}$ in a Soxhlet apparatus. Both, untreated veneers that were directly conditioned at $20^{\circ} \mathrm{C} / 65 \% \mathrm{RH}(\mathrm{CO})$ and untreated veneers that were dried at $130{ }^{\circ} \mathrm{C}$ for $24 \mathrm{~h}$ (CO 130) prior to conditioning served as controls. The initial area at the point of time when the droplets were placed on the surface $\left(t_{0}\right)$ was set as $0 \%$. The wettability was expressed by the cumulative enlargement versus time.

The measurements with glues were carried out on five knife-cut spruce veneer strips with radial texture $(50 \times 50 \times$ $\left.0.7 \mathrm{~mm}^{3}\right)$. The veneers were immersed in a $1 \%(\mathrm{wt} / \mathrm{wt})$ AKD or paraffin solution for $1.5 \mathrm{~h}$ and dried at $103^{\circ} \mathrm{C}$ $(24 \mathrm{~h})$, respectively. Five veneer strips that were water impregnated and dried served as controls. After climatizing to equilibrium moisture content $\left(20^{\circ} \mathrm{C} / 65 \% \mathrm{RH}\right)$, extensions of $5 \mathrm{PF}$ and UF resin droplets $(10 \mu \mathrm{l})$ were recorded every $30 \mathrm{~s}$ during the total duration of $600 \mathrm{~s}$ on each strip.

\subsection{Cold water extraction and $\mathrm{pH}$-value}

Samples ( $5 \mathrm{~g}$ ovendried) of the veneers, which were used for measuring water wettability and FTIR spectra, were extracted with distilled water $(150 \mathrm{ml})$ in Erlenmeyer flasks $(500 \mathrm{ml})$ at room temperature $\left(20^{\circ} \mathrm{C}\right)$. The flasks were placed on a shaker for $24 \mathrm{~h}$. After extraction, water was filtrated and used for the determination of the $\mathrm{pH}$ value (WTW, inoLab pH Level 2, Weilheim, Germany).

\section{Results and discussion}

\subsection{Thickness swelling and water uptake}

AKD did not reduce the thickness swelling and water uptake in Process 1 and Process 2 as compared to the controls and the paraffin references (Fig. 1). The results of boards from Process 2 are in contradiction to findings of previous investigations on UF-bonded particleboards (Hundhausen et al. 2009a,b). In these earlier studies, AKD-treated chips that were cured at $130{ }^{\circ} \mathrm{C}(24 \mathrm{~h})$ prior to gluing and pressing $\left(12 \mathrm{~s} \mathrm{~mm}^{-1}\right)$, resulted in strongly reduced thickness swelling and water uptake as compared to controls. In contrast, neither the admixture of AKD to the UF resin nor separate spraying of AKD and UF resin in a back-to-back application led to significant hydrophobicity when pre-curing was omitted. In consequence, the pressing time was extended from 12 to 30 and $60 \mathrm{~s} \mathrm{~mm}^{-1}$ in order to induce esterification during pressing and make separate pre-curing of the chips unnecessary. This attempt, however, failed. The results led to the conclusion that esterification does not take place in the press because water vapor hydrolyzes AKD before it reacts with wood hydroxyl groups.

The high thickness swelling and water uptake of PFbonded particleboards in Process 1 confirmed the hypothesis of an AKD hydrolysis by vapor. The high thickness swelling and water uptake of PF-bonded boards in Process 2 is most likely explained by the different $\mathrm{pH}$ values of UF and $\mathrm{PF}$ resins. UF resin (Kaurit 350) has a pH of 7.5-9.5 and is acidcatalyzed, whereas PF resins have $\mathrm{pH}$ values of $8.5-10.5$
Fig. 1 Thickness swelling (a) and water uptake (b) of control boards (CO), paraffin references (PAR), and boards made from AKD-treated chips (AKD) after $24 \mathrm{~h}$ water submersion. In Process 1 (P1), chips were pressed for 15,30 , and $60 \mathrm{~s} \mathrm{~mm}^{-1}$ without a pre-curing. In Process 2 (P2), chips were pressed for $15 \mathrm{~s} \mathrm{~mm}^{-1}$ after 6 , 12 , and $24 \mathrm{~h}$ pre-curing Abb. 1 Dickenquellung (a) und Wasseraufnahme (b) der Kontrollplatten (CO), der Paraffinreferenzen (PAR) und der Platten aus AKD behandelten Spänen (AKD) nach $24 \mathrm{~h}$ Wasserlagerung. Im ersten Prozess (P1) war die Presszeit 15,30 und $60 \mathrm{~s} \mathrm{~mm}^{-1}$. Im zweiten Prozess (P2) wurden die Späne nach 6, 12 und $24 \mathrm{~h}$ Vortrocknung bei $15 \mathrm{~s} \mathrm{~mm}^{-1}$ verpresst
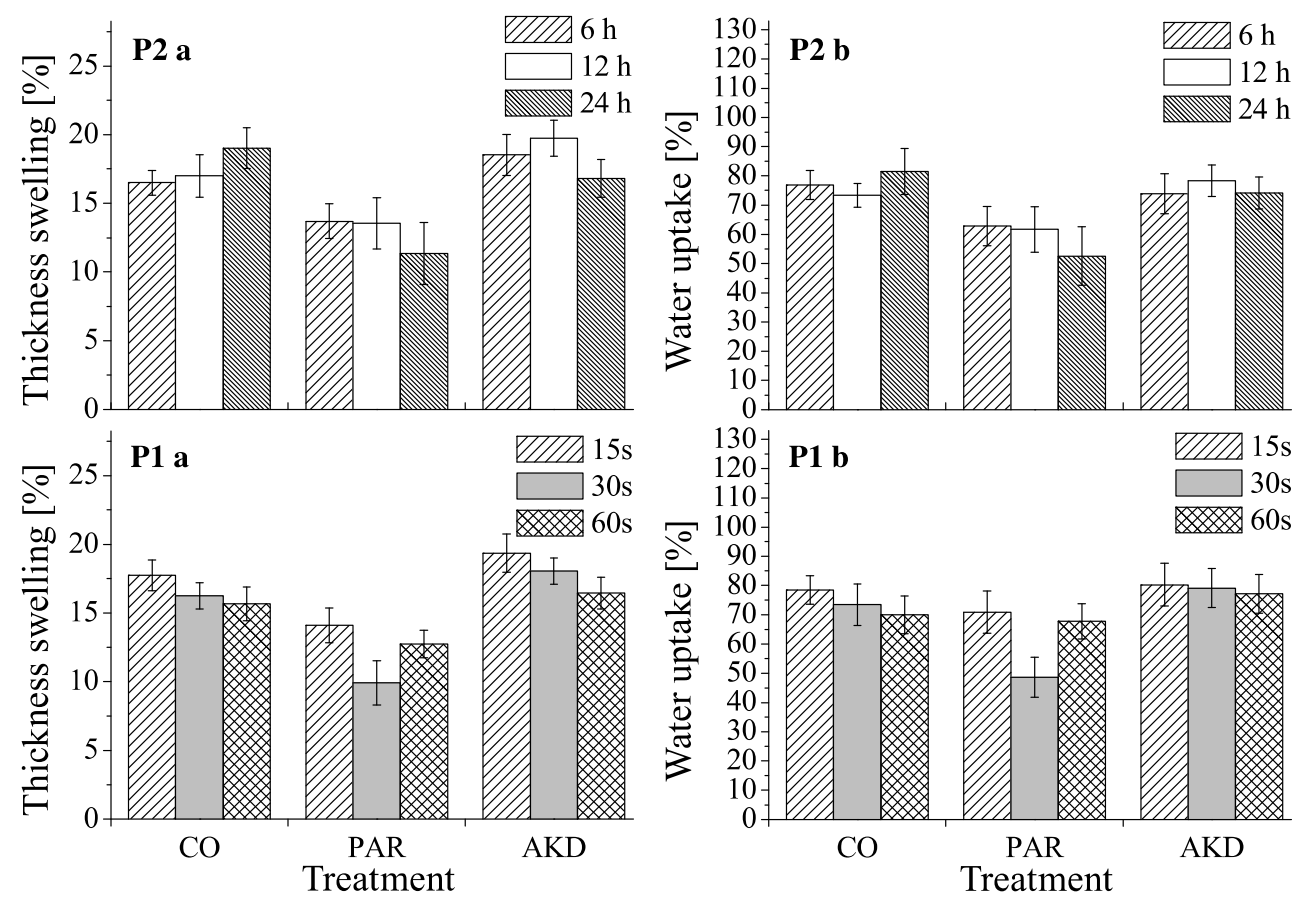
Fig. 2 IB (c) and MOR (d) of control boards $(\mathrm{CO})$, paraffin references (PAR), and boards made from AKD-treated chips (AKD). In Process 1 (P1), chips were pressed 15,30 , and $60 \mathrm{~s} \mathrm{~mm}^{-1}$ without a pre-curing. In Process 2 (P2), chips were pressed at $15 \mathrm{~s} \mathrm{~mm}^{-1}$ after 6,12 , and $24 \mathrm{~h}$ pre-curing

Abb. 2 Querzugfestigkeit (c) und Biegefestigkeit (d) der Kontrollplatten (CO), der Paraffinreferenzen (PAR) und der Platten aus AKD behandelten Spänen (AKD). Im ersten Prozess (P1) war die Presszeit 15, 30 und $60 \mathrm{~s} \mathrm{~mm}^{-1}$. Im zweiten Prozess (P2) wurden die Späne nach 6, 12 und $24 \mathrm{~h}$ Vortrocknung bei $15 \mathrm{~s} \mathrm{~mm}^{-1}$ verpresst

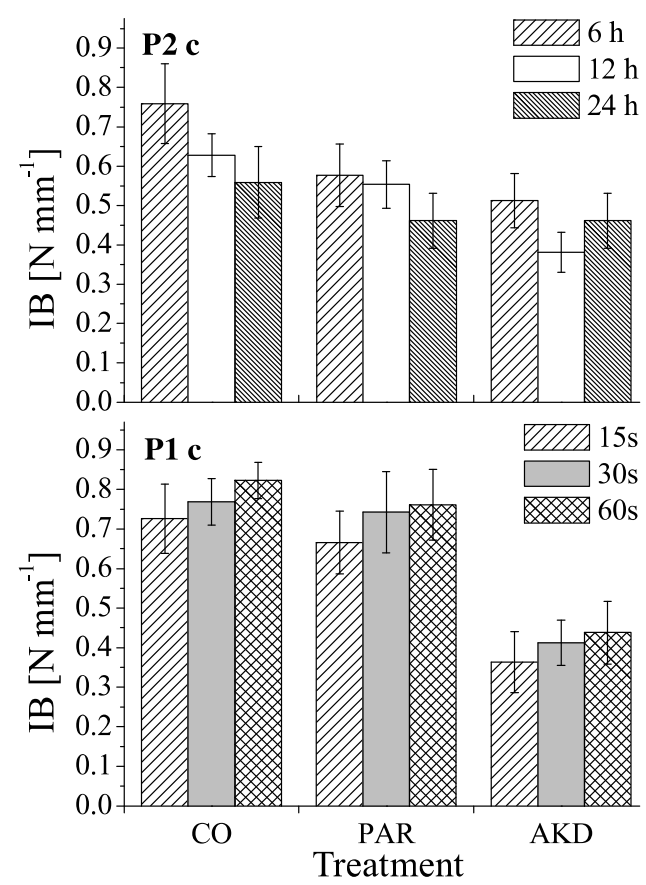

(Bakelite PF 1842 HW) and 11-13 (Bakelite PF 2506 HW) and are basic-catalyzed. The alkaline environment of the aqueous PF system is assumed to cause a saponification of esters that were formed between AKD and wood hydroxyl groups during pre-curing (Process 2).

\subsection{Strength properties and $\mathrm{pH}$ value}

In Process 1 (Fig. 2 P1), the increased IB at extended pressing times are attributed to promoted polycondensation as the formation rate of methylene bonds between resols is a function of time (Zeppenfeld and Grunwald 2005). The core temperature was 136,157 , and $183^{\circ} \mathrm{C}$ after 5,10 , and $20 \mathrm{~min}$ of pressing, respectively. However, it should also be taken into account that elevated temperatures facilitate a release of acids, which, in turn, impedes the hardening of the alkaline reacting PF resin. Thermohydrolytic decomposition of hemicelluloses starts in the range of $120-150^{\circ} \mathrm{C}$ and results in a release of volatile acids, such as formic and acetic acid. It has been found that the acidity of chips from different species, the drying process, and the pressing conditions influence the gluability (Packman 1960, Poblete and Roffael 1985, Roffael 1989). However, the positive effect of the elevated middle layer temperatures apparently exceeds the negative effect of formed acids in Process 1.

The pressing time was not changed in Process 2 in contrast to Process 1 . Thus, the temperature influence can be regarded as constant. The decrease of IB with the extended curing times could be addressed to the formation of acetic and formic acid during pre-curing at $130{ }^{\circ} \mathrm{C}$ (Fig. 2 P2). Controls that were cured exhibited a lower $\mathrm{pH}$ value than
Table 1 Comparison between $\mathrm{pH}$-values of cold water extractives from AKD-treated veneers (AKD), cured controls (CO (cur)), and untreated controls (CO (untreated))

Tabelle 1 Vergleich der $\mathrm{pH}$ Werte von Kaltwasserextrakten von AKD behandelten Furnieren (AKD), getrockneten Furnieren (CO (cur)) und unbehandelten Furnieren (CO (untreated))

\begin{tabular}{lc}
\hline Treatment & $\mathrm{pH}$-value $\left(20^{\circ} \mathrm{C}\right)$ \\
\hline AKD (WPG 7.5\%) & 4.1 \\
CO (cur) & 5.3 \\
CO (untreated) & 5.9 \\
\hline
\end{tabular}

untreated controls (Table 1). The $\mathrm{pH}$ increase due to curing was shown at spruce veneers because the industrial particleboard chips comprised a variety of wood species and qualities.

AKD reduced the IB of PF-bonded boards more than paraffin did. Similar observations were made for UF-bonded boards produced from AKD-treated and cured chips (Hundhausen et al. 2009a,b). The difference is that UF-bonded boards with AKD exhibited high water repellency. It was inferred that the hydrophobic surfaces of AKD-treated chips affect the mechanical interlock between UF-resin and the interspaces of wood. In contrast, the high thickness swelling and water uptake values of PF-bonded boards made from AKD-treated chips do not explain the low IB. It rather seems that the acidity of the AKD dispersion lowers the $\mathrm{pH}$ of the $\mathrm{PF}$ resin and hinders its condensation.

Commercial AKD dispersions for the paper industry have $\mathrm{pH}$ ranging from 2.5-3.5, acidulated with sulfuric or hydrochloric acid (Neimo 1999) in order to extend the storage time because the hydrolysis rate rises with increasing alkaline conditions (Neimo 1999, Hubbe 2006). At the same 
time, esterification is facilitated by increasing $\mathrm{pH}$. Lindström and O'Brian (1986) reported that the activation energy for the reaction between bleached kraft pulp and AKD was $72 \mathrm{~kJ} / \mathrm{mol}$ at $\mathrm{pH} 4$, decreasing linearly with $\mathrm{pH}$ to $54 \mathrm{~kJ} / \mathrm{mol}$ at $\mathrm{pH} 10$.

The influence of the $\mathrm{pH}$ value on the gluability was also reflected in the different IB of boards with AKD in Process 1 and 2. In Process 1, chips were first sprayed with the AKD dispersion ( $\mathrm{pH}$ of 2.5-4.5) and then sprayed with PF resin. In Process 2, chips were sprayed with the AKD dispersion, then cured, and finally resinated. The $\mathrm{pH}$ of the $\mathrm{PF}$ resin was probably less affected in Process 2 than in 1 since the majority of acids, which stabilize the AKD dispersion, evaporates during pre-curing; however, the $\mathrm{pH}$ value of AKD-treated and cured veneer strips was slightly below that of controls (Table 1). This is only explained by residual acids from the AKD dispersion.

\subsection{FTIR analyses}

The FTIR analysis of AKD-treated core layer chips before extraction showed two elevated absorption bands (AKD b.E.) between 2800 and $3000 \mathrm{~cm}^{-1}$ that originate from methyl and methylene groups of AKD's alkyl chains (Fig. 3). In addition, the band between 1700 and $1750 \mathrm{~cm}^{-1}$ is increased in comparison to the controls. This band indicates carbonyl groups, originating from hemicelluloses and lignin (Hergert 1971) as well as AKD, probably both of hydrolyzed (ketones) and non-hydrolyzed form (Seo and Cho 2005). In case of $\beta$-keto-ester formation between AKD and wood hydroxyl groups, additional carbonyl groups emerge. The spectra of AKD-treated chips after extraction (AKD a. E.) do not exhibit any deviations from those of extracted controls (CO a. E.).

Since the amount of AKD on the chips was probably too small for detection (theoretic WPG of 1\%, calculation based on applied AKD dispersion), veneer strips (WPG of 7.5\%) were analyzed. The absorption bands between 2800 and
$3000 \mathrm{~cm}^{-1}$ and 1700 and $1750 \mathrm{~cm}^{-1}$ were strongly reduced after extraction but still exceeded those of control veneers (Fig. 3). This indicates that AKD can be partially bonded on the chips under the applied curing conditions. These results comply with previous findings of extraction studies in combination with FTIR analyses (Hundhausen et al. 2009a).

The low addition of AKD (0.05-0.2\%, based on mass) in paper production makes the detection and quantification difficult. Roberts and Garner (1985) assumed that only $0.006-0.01 \%(\mathrm{wt} / \mathrm{wt})$ of AKD products are retained after extraction of sized paper. Although the issue of esterification is still debated in the scientific community, several researchers have reported that AKD is covalently bonded. Kamutzki and Krause (1982) investigated AKDs and their reaction products in neutral sizing conditions by means of high pressure liquid chromatography and came to the conclusion that esterification occurs. Nahm (1986) reported of ${ }^{13} \mathrm{C}-\mathrm{NMR}$ and/or infrared spectroscopy that provide direct evidence for $\beta$-keto ester formation between AKD and methyl $\alpha$-Dglucopyranoside, maltose, cellobiose, microcrystalline cellulose, and a bleached kraft pulp. Lindström and O'Brian (1986) and Lindström and Söderberg (1986a,b,c) conducted several studies on the mechanism of sizing with AKDs. Their investigations with radioactive labelled $\left({ }^{14} \mathrm{C}\right)$ AKD showed that no sizing is obtained unless AKD is covalently bonded with the fibers; moreover, only small quantities between 0.008 and $0.038 \%$ of esterified AKD, based on mass, are enough to provide sufficient water repellency to paper fibers. Dumas and Evans (1986) found that only 0.01$0.07 \%$ coverage of the paper surface provide a sufficient sizing effect.

\subsection{Surface wettability}

The drop extension measurements with UF and PF resins revealed that AKD and paraffin treatments decrease the wettability as compared to the controls (Fig. 4a). ANOVA analysis of UF drop extensions after $300 \mathrm{~s}$ indicated signifi-
Fig. 3 FTIR spectra of AKD-treated chips and veneers before (b.) and after (a.) Soxhlet extraction (E.)

Abb. 3 FTIR Spektra der AKD behandelten Späne (links) und Furniere (rechts) vor (b.) und nach (a.) einer Soxhletextraktion mit Toluol (E.)

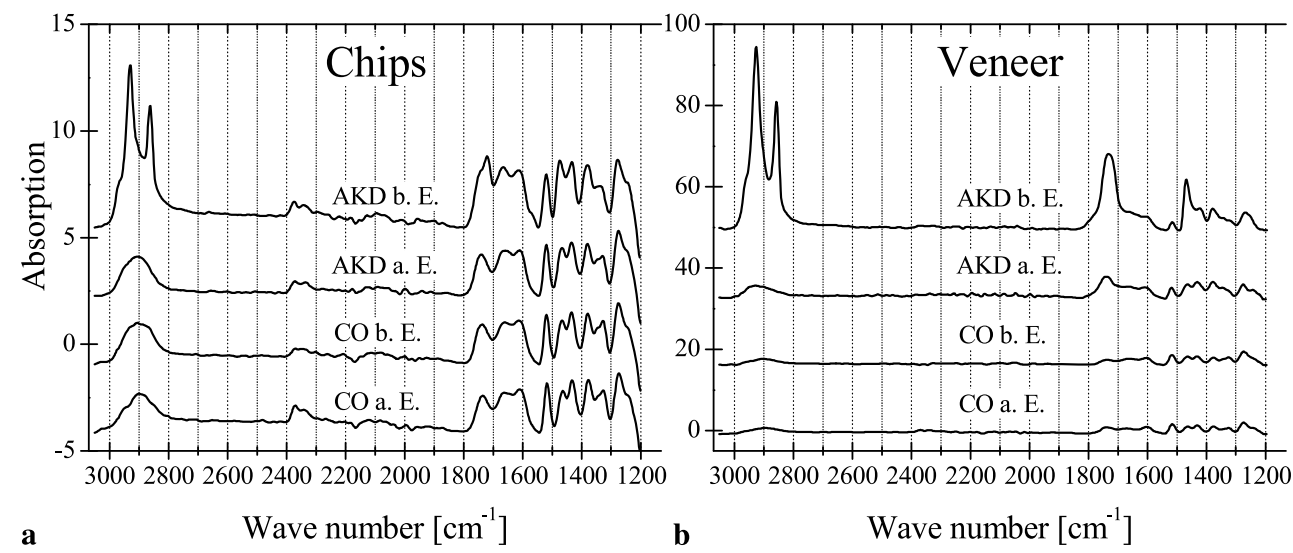



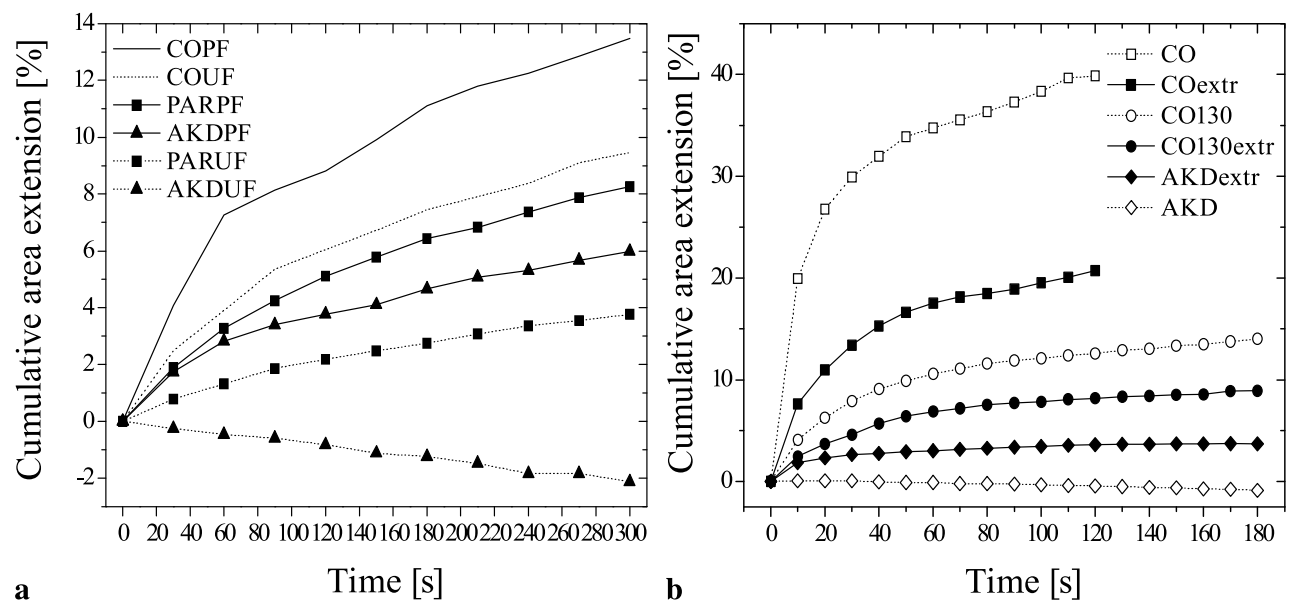

Fig. 4 a Cumulative area extension against measurement time of PF and UF drops on untreated, paraffin-, and AKD-treated veneer strips. b Cumulative area extension against measurement time of water drops on untreated controls $(\mathrm{CO})$, cured controls $\left(130{ }^{\circ} \mathrm{C} / 1 \mathrm{~h}\right)$, and $\mathrm{AKD}$-treated veneers strips before and after toluene extraction (extr.)

Abb. 4 a Kumulative Flächenvergrößerung in Abhängigkeit der Messzeit von PF und UF Leimtropfen auf unbehandelten (CO), paraffinbehandelten (PAR) und AKD behandelten (AKD) Furnierproben. b Kumulative Flächenvergrößerung in Abhängigkeit der Messzeit von Wassertropfen auf unbehandelten Kontrollen $(\mathrm{CO})$, getrockneten Kontrollen $\left(130^{\circ} \mathrm{C} / 1 \mathrm{~h}\right)$ und AKD behandelten (AKD) Furnierproben vor und nach einer Toluolextraktion (extr.)

cant differences between controls (CO), AKD- (AKD), and paraffin- (PAR) treated veneers at the 0.05 probability level. The mean area of UF drops on AKD-treated veneers (AKD UF) even decreased over time, which is attributed to the evaporation of water.

The extensions of PF drops were faster than those of UF drops, which is most likely to be explained by the higher solid content of the UF resin. Because of different solid contents, the measurements on veneers do not describe the real mechanism how UF and PF resin spread on AKD-treated chips in board production. The solid contents of the UF and the PF resin are adjusted according to the target moisture content of chips before pressing. This, in turn, depends on the moisture content of chips before gluing, the type and the amount of hardener and resin. Although a direct comparison between PF and UF measurements is not possible, the drop extension results clearly showed that the wettability decreased in the order of $\mathrm{CO}>\mathrm{PAR}>\mathrm{AKD}$.

Low wettability hampers the spreading over the chip and the penetration of the water-born resins into the wood (Rowell et al. 1987). This hinders the adhesion between the chip surface and the PF resin and might explain why AKD affects the IB of boards more than paraffin does.

The extension rates of water drops were lower on AKDtreated veneers than on controls before Soxhlet extraction (Fig. 4b). The different results between controls that were dried at $130^{\circ} \mathrm{C}(\mathrm{CO} 130)$ prior to conditioning and controls that were not dried $(\mathrm{CO})$ suggest that hornification during curing contributes to the hydrophobicity of AKD-treated veneers. Hornification has been frequently associated with the formation of irreversible or partly reversible hydrogen bond- ing caused by drying (Newman and Hemmingson 1997, Gruber and Weigert 1998). The wettability of AKD-treated veneers, however, increased after extraction (AKDextr) but was still above that of controls (CO130extr). Assuming that the extraction with toluene removed all unreacted AKD, the results show that AKD is partially esterified and that this part increases the wettability as compared to the controls; however, the different wettabilities before and after extraction also reveal that hydrolyzed AKD in the form of ketones contributes to hydrophobicity.

This is in agreement with findings of Lee and Luner (2005) who assumed that non-bonded AKD, e.g., in form of unreacted AKD, can contribute to sizing by a synergistic effect with bonded AKD. Nahm (1986) observed that bonded AKD molecules tended to be agglomerated, indicating that association between the hydrophobic groups supports an alignment of unreacted AKD molecules towards hydroxyl groups on the paper surface. The paper sizing efficiency of ketones was estimated to be 2-3 times lower than that of AKD (Lindström and Söderberg 1986a).

\section{Conclusion}

Wettability studies revealed that an AKD treatment with subsequent curing imparts hydrophobicity to wood chips. The water-related properties of particleboards, however, depend on the resin used. In contrast to UF-bonded boards previously investigated, PF-bonded boards made from AKDtreated and cured chips did not exhibit increased water resistance. FTIR and wettability analyses after toluene extraction 
indicated that AKD partially bonds to the chip surface, and that this part accounts for most of the reduction in surface wettability. Thus, the different effectiveness of UF and PF resin is ascribed to the higher $\mathrm{pH}$ of $\mathrm{PF}$ resin that may cause an alkaline cleavage of esters. The back-to-back application of AKD and PF resin failed probably due to a hydrolysis of AKD by water vapor during hot pressing. The use of isocyanate with amines could help to clarify the role of hydrolysis in AKD treatments.

Acknowledgement Sincere thanks are expressed to the "Deutsche Bundesstiftung Umwelt" (DBU) for granting Ulrich Hundhausen a doctoral scholarship. The authors would also like to thank the companies Kemira, Sasol, Danzer, BASF, and Pfleiderer for providing materials.

\section{References}

Davis JW, Robertson WH, Weisgerber CA (1956) A new sizing agent for paper - Alkylketene dimers. Tappi 39(1):21-23

DIN 52362:1965 Testing of wood chipboards; bending test, determination of bending strength

Dumas DH, Evans DB (1986) AKD-cellulose reactivity in papermaking systems. Proc. Tappi 1986 Papermakers Conf., Atlanta

EN 317:1993 Particleboards and fibreboards; determination of swelling in thickness after immersion in water

EN 319:1993 Particleboards and fibreboards; determination of tensile strength perpendicular to the plane of the board

Gruber E, Weigert J (1998) Chemische Modifizierung von Zellstoffen zur Verminderung ihrer Verhornungsneigung - Chemical modification of pulp to reduce its hornification tendency. Papier 52:20-26

Hergert HL (1971) Infrared spectra. In: Sarkanen KV, Ludwig CH (eds) Lignins - occurrence, formation, structure and reactions, 1 edn. Wiley-Interscience, New York, pp 267-297

Hubbe MA (2006) Paper's resistance to wetting - A review of internal sizing chemicals and their effects. BioResources 2(1):106-145

Hundhausen U, Militz H, Mai C (2009a) Use of alkyl ketene dimer (AKD) for surface modification of particleboard chips. Holz Roh- Werkst 67(1):37-45

Hundhausen U, Stohldreier R, Militz H, Mai C (2009b) Procedural influence on the properties of particleboards made from AKD modified chips. Holz Roh- Werkst 67(3):303-311

Kamutzki W, Krause T (1982) Investigations on neutral sizing with alkyldiketen. Papier 36(7):311

Lee HL, Luner P (2005) Effect of relative humidity and unreacted AKD on AKD sizing. Nord Pulp Pap Res J 20(2):227-231
Lindström T, O'Brian H (1986) On the mechanism of sizing with alkylketene dimers. Part 2: The kinetics of reaction between alkylketene dimers and cellulose - Studies on the amount of alkylketene dimer required for sizing differnt pulps. Nord Pulp Pap Res J 1(1):34-42

Lindström T, Söderberg G (1986a) On the mechanism of sizing with alkylketene dimers. Part 1: Studies on the amount of alkylketene dimer required for sizing differnt pulps. Nord Pulp Pap Res J 1(1):26-33

Lindström T, Söderberg G (1986b) On the mechanism of sizing with alkylketene dimers. Part 3: The role of $\mathrm{pH}$, electrolytes, retention aids, extractives, Ca-lignosulfonates and mode of addition on alkylketene dimer retention. Nord Pulp Pap Res J 1(2):31-38

Lindström T, Söderberg G (1986c) On the mechanism of sizing with alkylketene dimers. Part 4: The effects of $\mathrm{HCO}_{3}^{-}$ions and polymeric reaction accelerators on the rate of reaction between alkylketene dimers and cellulose. Nord Pulp Pap Res J 1(2):39-45

Nahm SH (1986) Evidence for covalent bonding between ketene dimer sizing. Agents and cellulose. J Wood Chem Tech 6(1):89-112

Neimo L (1999) Papermaking chemistry. Technical Association of the Pulp and Paper Industry, Helsinki, Fapet Oy

Newman RH, Hemmingson JA (1997) Cellulose cocrystallization in hornification of kraft pulp. 9th international symposium of wood and pulp chemistry, Montréal

Packman DF (1960) The acidity of wood. Holzforschung 14(6):178183

Poblete H, Roffael E (1985) Über chemische Veränderungen in Holzspänen bei der Herstellung von Harnstoff-Formaldehydharzgebundenen Spanplatten - On chemical changes in wood particles during pressing with urea formaldehyde resins as binder. Holz Roh- Werkst 43(2):57-62

Roberts JC, Garner DN (1985) The mechanism of alkyl ketene dimer sizing of paper. Part 1. Tappi 68(4):118-121

Roffael E (1989) Abgabe von flüchtigen organischen Säuren aus Holzspänen und Holzspanplatten. Holz Roh- Werkst 47:447-452

Roffael E, Schneider T, Dix B, Buchholz T (2005) On paraffin sizing of medium density fiberboards (MDF). Part 1: Influence of the chemical composition of paraffin and type of emulsifier on the hydrophobic properties of MDF. Holz Roh- Werkst 63(3):192203

Rowell RM, Youngquist JA, Sachs IB (1987) Adhesive bonding of acetylated aspen flakes, Part 1. Surface changes, hydrophobicity, adhesive penetration and strength. Int J Adhes Adhes 7(4):183-188

Seo WS, Cho NS (2005) Effect of water content on cellulose/AKD reaction. Appita J 58(2):122-126

Youngquist JA (1999) Wood-based composites and panel products. General technical report FPL; GTR-113, Service UF, For Prod Lab 10.11-10.31

Zeppenfeld G, Grunwald D (2005) Klebstoffe in der Holz- und Möbelindustrie. DRW-Verlag Weinbrenner GmbH \& Co. KG, Leipzig 